\title{
Peningkatan Kapasitas Masyarakat dan Identifikasi Potensi Wisata Dalam Pengembangan Desa Watu Tiri Sebagai Desa Wisata
}

\author{
Ida Ayu Rostini ${ }^{1}$, Roseven Rudiyanto ${ }^{2}$, Irna Karina J. Kaban ${ }^{3}$, Septian Hutagalung ${ }^{4}$ \\ ${ }^{1}$ Politeknik eLBajo Commodus, Labuan Bajo, Indonesia, email: idayrost@ poltekelbajo.ac.id \\ ${ }^{2}$ Politeknik eLBajo Commodus, Labuan Bajo, Indonesia, email: roseven@ poltekelbajo.ac.id \\ ${ }^{3}$ Politeknik eLBajo Commodus, Labuan Bajo, Indonesia \\ ${ }^{4}$ Politeknik eLBajo Commodus, Labuan Bajo, Indonesia
}

\begin{tabular}{|c|c|}
\hline \\
\hline \\
\hline $\begin{array}{ll}\text { Diterima } & : 9 \text { Januari } 2021 \\
\text { Revisi } & : 11 \text { Januari 2021 }\end{array}$ & $\begin{array}{l}\text { Informasi artikel } \\
\text { Sejarah } \\
\text { artikel } \\
\text { Diterima }\end{array}$ \\
\hline \multicolumn{2}{|c|}{ Revisi $\quad: 11$ Januari 2021} \\
\hline \multicolumn{2}{|c|}{$\begin{array}{ll}\text { Revisi } & : \text { 11 Januari } 2021 \\
\text { Dipublikasikan } & : \text { 22 Januari } 2021\end{array}$} \\
\hline
\end{tabular}

Kata kunci:

Potensi

Desa

Wisata

Peningkatan

Kapasitas

\section{ABSTRAK}

Kegiatan pengabdian kepada masyarakat ini bertujuan meningkatkan kapasistas masyarakat Desa Watu Tiri dalam bidang pariwisata dan mengidentifikasi potensi wisata yang ada. Dalam kegiatan ini ada tiga pendekatan yang dilakukan, diantaranya Participatory Rural Appraisal (PRA), Community-based development, dan partisipatif. Pengumpulan data menggunakan teknik focus group discussion (FGD) dan observasi lapangan. Potensi wisata yang teridentifikasi dalam kegiatan pengabdian masyarakat ini, diantaranya Pantai Mberenang dan sumber mata air panas sebagai potensi wisata alam, sedangkan potensi budaya diantaranya kegiatan menenun songke para kaum perempuan dan upacara adat di Desa Watu Tiri. Dapat disimpulkan bahwa dalam pengembangan Desa Watu Tiri sebagai desa wisata, masih diperlukan kegiatan pendampingan seperti pelatihan promosi dan e-commerce, pelatihan pemanduan dan bahasa inggris, dan peningkatan system mitigasi di Kawasan Pantai Mberenang untuk memperbaiki citra.

\section{ABSTRACT}

Keywords:

Potency

Village

Travel

Enhancement

Capacity
Community Capacity Building and Identification of Tourism Potential in the Development of Watu Tiri Village as a Tourism Village

This community service activity aims to increase the capacity of the Watu Tiri Village community in the tourism sector and identify existing tourism potentials. In this activity, there are three approaches taken, including Participatory Rural Appraisal (PRA), Community-based development, and participatory. Data collection used focus group discussion (FGD) techniques and field observations. The tourism potentials identified in this community service activity include Mberenang Beach and hot springs as natural tourism potential, while cultural potential includes the activity of weaving songke for women and traditional ceremonies in Watu Tiri Village. It can be concluded that in developing Watu Tiri Village as a tourism village, assistance activities such as promotion and e-commerce training, guiding training and English language training, and improving the mitigation system in the Mberenang Beach area are still needed to improve its image.

Copyright $@ 2020$ Sekolah Tinggi Pariwisata AMPTA. All Right Reserved

\section{Pendahuluan}

Pariwisata di Kabupaten Manggarai Barat mengalami kemajuan yang pesat dalam beberapa tahun terakhir. Hal ini terindikasi dari kunjungan wisatawan nusantara dan mancanegara yang mengalami peningkatan dan pembangunan fasilitas akomodasi yang cukup massif. Namun, pertumbuhan tersebut hanya dinikmati oleh sebagian kecil masyarakat dan hanya terpusat di area perkotaan serta Taman Nasional Komodo yang menjadi destinasi pariwisata utama dan telah mendunia. Perkembangan 
pariwisata yang sangat pesat di Kabupaten Manggarai Barat belum mampu mensejahterakan masyarakat daerah secara luas, bahkan cenderung terjadi ketimpangan pembangunan antara ibukota kabupaten dengan kecamatan- kecamatan lainnya. Desa Watu Tiri merupakan salah satu dari lima belas desa di Lembor Selatan, kecamatan yang yang terletak di bagian selatan Kabupaten Manggarai Barat. Kegiatan pemerintahan Lembor Selatan berpusat di desa ini, tepatnya di Lengkong Cepang yang berjarak sekitar $92 \mathrm{~km}$ dari Labuan Bajo, ibukota Kabupaten Manggarai Barat.

Pada mulanya, wilayah Desa Watu Tiri merupakan bagian dari wilayah Desa Suru Numbeng, namun kini telah mengalami pemekaran. Luas wilayah Desa Watu Tiri berkisar $14 \mathrm{~km} 2$ atau 6 persen dari total luas Kecamatan Lembor Selatan dan menjadi desa yang memiliki luas terbesar setelah Desa Nangalili. Desa Watu Tiri terdiri atas 4 (empat) dusun, yakni Dusun Kulang, Lengkong Cepang I, Lengkong Cepang II, dan Wae Mege serta 16 RT. Desa Watu Tiri berbatasan dengan Desa Suru Numbeng di sebelah utara serta Desa Watu Waja di sebelah selatan. Sedangkan di sebelah timur Desa Watu Tiri berbatasan dengan Desa Benteng Tado dan Laut Sawu di sebelah barat. Sebagai bagian dari wilayah Kabupaten Manggarai Barat dan berbatasan dengan Kabupaten Manggarai, posisi Desa Watu Tiri cukup strategis sebab menjadi salah satu jalur alternatif menuju daya tarik wisata yang sudah dikenal dunia, yaitu Kampung Adat Waerebo. Secara topografi, sebagian besar Desa Watu Tiri berada pada dataran tinggi, yaitu 342 meter dari permukaan laut, serta berbatasan pula dengan laut. Desa Watu Tiri terletak pada ketinggian $0-70 \mathrm{~m}$ di atas permukaan air laut dengan rerata suhu berkisar antara $25-37^{\circ} \mathrm{C}$ (RPJMDes Watu Tiri $\left.2019-2024\right)$.

Penulis berpendapat bahwa Desa Watu Tiri pun memiliki sejumlah potensi wisata, baik wisata alam maupun wisata budaya, namun belum dikembangkan secara optimal. Kendala yang diihadapi diantaranya adalah kurangnya pemahaman masyarakat tentang pariwisata, dan belum adanya pendataan potensi wisata, sehingga belum adanya produk wisata yang bisa ditawarkan. Salah satu potensi alam yang ada di Desa Watu Tiri adalah Pantai Mberenang. Pantai Mberenang sendiri merupakan termasuk dalam Kawasan Taman Nasional Perairan (TNP) Laut Sawu (Kementerian Kelautan dan Perikanan, 2020). Kebiasaan menenun songke sebagian besar para kaum perempuan yang masih bertahan hingga saat ini merupakan kearifan lokal yang bisa menjadi potensi wisata budaya. Marx (2020) berpendapat bahwa tradisi tenun dibawa ke Nusa Tenggara Timur oleh pedagang Islam sekitar abad ke-16. Dikatakan lebih lanjut bahwa tenun songke adalah tenunan khas daerah Manggarai yang cara pembuatannya mirip tenunan songket dari Sumatra, dimana warna dasar kain songke hitam, sedangkan motifnya berwarna-warni (Marx, 2002). Kain tenun secara adat dan budaya Nusa Tenggara Timur memiliki banyak fungsi. Dari sebagai bagian pakaian sehari-hari, persembahan kepada tamu, hingga perlindunagan dari bencana alam dan roh jahat (Thalo, 2003 dalam Susilawati, 2010). Potensi-potensi tersebut bisa dijadikan peluang bagi Desa Watu Tiri untuk dikembangkan menjadi desa wisata di Kabupaten Manggarai Barat, terlebih letaknya di jalur perlintasan Labuan Bajo - Kampung Adat Waerebo.

Dalam mewujudkan Desa Watu Tiri sebagai desa wisata dibutuhkan perencanaan potensi wisata yang komprehensif sehingga dalam pengembangannya dapat lebih terarah. Salah satu Langkah awal perencanaan tersebut adalah pendataan potensi wisata yang ada. Dengan adanya daftar potensi wisata, diharapkan ada produk wisata yang dapat ditawarkan, sehingga aktivitas pariwisata di Desa Watu Tiri nantinya mampu menggerakkan perekonomian lokal, membuka lapangan pekerjaan dan peluang usaha baru, melestarikan kebudayaan lokal, serta meningkatkan kualitas hidup masyarakat pedesaan.

Tujuan dari kegiatan pengabdian ini diantaranya: 1) Meningkatnya kapasitas masyarakat lokal terhadap pariwisata; dan 2) Mengidentifikasi potensi dan produk pariwisata di lingkup desa, baik alam maupun budaya.

\section{Metode}

Untuk mencapai tujuan kegiatan, penyelenggaraan pengabdian masyarakat di Desa Watu Tiri ini dilakukan dengan melalui beberapa pendekatan, diantaranya: 1) Model Participatory Rural Appraisal (PRA) dapat mengungkapkan dan menganalisis situasi mereka sendiri serta secara optimal merencanakan dan melaksanakan tekat itu di desanya sendiri (Mikalsen dalam Hudayana et al, 2019). PRA sendiri menekankan keterlibatan masyarakat dalam keseluruhan kegiatan mulai dari perencanaan, pelaksanaan, dan evaluasi program kegiatan; 2) Model Community Based-Development yakni pendekatan yang melibatkan masyarakat secara langsung sebagai subjek dan objek pelaksanaan 
pengabdian pada masyarakat. Budimanta menjelaskan bahwa community development memiliki keunggulan, diantaranya diselenggarakan secara sistematis, terencana, dan diarahkan untuk memperbesar akses masyarakat guna mencapai kondisi sosial, ekonomi, dan kualitas kehidupan yang lebih baik (Triono, 2014); 3) Persuasif yaitu pendekatan yang bersifat himbauan dan dukungan tanpa unsur paksaan bagi masyarakat untuk berperan aktif dalam pelaksanaan kegiatan pengabdian pada masyarakat.

Focus Group Discussion (FGD) dan observasi lapangan merupakan metode yang dilakukan dalam pengumpulan data. FGD sendiri dihadiri oleh perangkat desa, tokoh masyarakat, dan perwakilan masyarakat desa. Pada FGD, masyarakat diberikan pertanyaan mengenai potensi wisata, kelompok masyarakat yang sudah terbentuk, permasalahan yang dihadapi oleh masyarakat dalam mengembangkan pariwisata, dan harapan dan cita-cita yang ingin dicapai melalui pengembangan pariwisata di Desa Watu Tiri. Pada observasi lapangan, tim mengunjugi langsung tempat-tempat yang menjadi potensi wisata.

\section{Hasil dan Pembahasan}

FGD diselenggarakan di Kantor Desa Watu Tiri, mulai pukul dengan tujuan mengidentifikasi potensi pariwisata, kelompok masyarakat, permasalahan, dan cita-cita pengembangan pariwisata. Peserta dihadiri oleh sejumlah perangkat desa, tokoh budaya, tokoh masyarakat, dan perwakilan dari masyarakat. FGD yang dilaksanakan di masa pandemi COVID-19 ini membuat kehadiran peserta dibatasi. Meskipun begitu, selama pelaksanaan, para peserta yang hadir cukup antusias dan proaktif saat diskusi berlangsung dengan memberikan berbagai pendapat dan pandangan terkait aspek potensi, permasalahan, maupun harapan dalam pengembangan pariwisata di Desa Watu Tiri. Dengan adanya fasilitasi melalui FGD, masyarakat menjadi lebih memahami bagaimana mengidentifikasi serta mengkategorikan aspek-aspek yang dibutuhkan dalam merumuskan kebutuhan perencanaan dan pengembangan sebuah desa wisata. Untuk lebih jelasnya, hasil FGD bersama masyarakat diperlihatkan pada Tabel 1.

Tabel 1. Hasil FGD Masyarakat Desa Watu Tiri

\begin{tabular}{|c|c|c|c|}
\hline Potensi Pariwisata & $\begin{array}{c}\text { Kelompok } \\
\text { Masyarakat }\end{array}$ & Permasalahan & $\begin{array}{c}\text { Cita-cita } \\
\text { Pengembangan }\end{array}$ \\
\hline $\begin{array}{l}\text { 1. Pantai Mberenang } \\
\text { 2. Gumuk pasir } \\
\text { 3. Watu Tiri } \\
\text { 4. Gua Maria Pong Rojo } \\
\text { 5. Mbaru } \\
\text { Gendang } \\
\text { Kulang } \\
\text { 6. Cunca Rajong } \\
\text { 7. Kebiasaan menenun } \\
\text { 8. Ritual budaya: } \\
\text { penti, upacara } \\
\text { mareng } \\
\text { 9. Agrowisata } \\
\text { 10. Konservasi penyu }\end{array}$ & $\begin{array}{l}\text { 1. BUMDES } \\
\text { 2. Pokdarwis } \\
\text { 3. Kelompok } \\
\text { sanggar } \\
\text { budaya } \\
\text { 4. Kelom } \\
\text { pok } \\
\text { tenun }\end{array}$ & $\begin{array}{l}\text { 1. Keterbatasan SDM pariwisata } \\
\text { 2. Aksesibilitas \& amenitas } \\
\text { pariwisata kurang memadai } \\
\text { 3. Perawatan DTW belum } \\
\text { maksimal } \\
\text { 4. Narasi budaya dan sejarah } \\
\text { tidak terdokumentasikan } \\
\text { dengan baik } \\
\text { 5. Citra negatif tentang Pantai } \\
\text { Mberenang } \\
\text { 6. Kepemilikan lahan oleh } \\
\text { investor di area daya tarik } \\
\text { wisata } \\
\text { 7. Promosi dan pemasaran } \\
\text { berbagai produk pariwisata } \\
\text { belum maksimal }\end{array}$ & $\begin{array}{l}\text { 1. Perekonomian } \\
\text { masyarakat } \\
\text { meningkat } \\
\text { 2. Pelatihan dan } \\
\text { pendampingan } \\
\text { dalam } \\
\text { pengembangan } \\
\text { pariwisata } \\
\text { 3. Regulasi yang jelas } \\
\text { dari Pemerintah } \\
\text { Daerah (penetapan } \\
\text { Watu Tiri sebagai } \\
\text { desa wisata) }\end{array}$ \\
\hline
\end{tabular}

Sumber: Hasil FGD Masyarakat, 2020

Hasil FGD bersama masyarakat telah menghasilkan pemetaan potensi, permasalahan, serta citacita pengembangan desa wisata. Desa Watu Tiri memiliki beragam daya tarik wisata, baik wisata alam maupun wisata budaya. Pantai Mberenang, daya tarik wisata andalan yang membentang 8 (delapan) 
km dari Desa Nangalili hingga Desa Repi ini juga menjadi bagian dari wilayah Desa Watu Tiri. Dengan tipikal pantai selatan pada umumnya, Pantai Mberenang memiliki gumuk pasir putih yang tinggi hingga menyerupai bukit serta ombak yang cukup kencang karena berbatasan langsung dengan laut lepas. Dari arah timur, pengunjung dapat melihat jelas Pulau Mules serta samar-samar Pulau Sumba dari selatan. Pada hari libur, pantai ini tidak jarang didatangi wisatawan, khususnya wisatawan lokal. Seperti nama yang melekat pada desa ini, di Pantai Mberenang terdapat Watu Tiri, "watu" dalam bahasa Manggarai berarti batu. Watu Tiri yang cukup ramai dikunjungi terutama oleh wisatawan lokal ini pernah dikelola oleh Dinas Pariwisata dan Kebudayaan Kabupaten Manggarai Barat namun terhenti karena beberapa alasan, salah satunya musibah yang terjadi selama 3 tahun terakhir sehingga cukup meresahkan masyarakat dan memunculkan citra negatif terhadap Pantai Mberenang. Selain itu, terdapat pula Gua Maria Immaculata Pong Rojo yang letaknya $\pm 2 \mathrm{~km}$ dari Kantor Desa Watu Tiri. Gua yang berada di atas bukit dengan ketinggian 875 mdpl ini menjadi destinasi wisata religi bagi para umat Katolik di Lembor Selatan dan sekitarnya. Untuk mencapainya, pengunjung harus menempuh $\pm 4 \mathrm{~km}$ dengan berjalan kaki. Akses jalan masuk menuju gua belum memadai sehingga kunjungan wisatawan pun belum optimal ke tempat ini. Dari puncak gua, pengunjung dapat menikmati keindahan panorama alam pesisir Lembor Selatan dan Kota Lembor dari ketinggian.

Dalam tatanan budaya, masyarakat Desa Watu Tiri cukup menjunjung budaya dan adat istiadat yang diwarisi oleh para leluhur. Hal ini terbukti masih berlakunya tatanan budaya serta kearifan lokal pada setiap prosesi pernikahan dan ritual adat lainnya. Lembaga yang paling berperan dalam melestarikan tatanan adat istiadat dan budaya lokal ini adalah Lembaga Adat. Selain lembaga adat, ada pula sanggar milik kelompok, di antaranya kelompok sanggar budaya yang dirintis oleh SMKN 1 Lembor Selatan bernama Sanggar Sangku Lerong, di bawah asuhan Bapak Benny sekaligus guru Bahasa Inggris di sekolah tersebut. Sanggar tersebut tidak hanya mengajarkan kebudayaan Manggarai kepada para siswa, namun juga bentuknya ekstrakurikuler Bahasa Inggris, khususnya dalam bidang pemanduan wisata. Selain mengisi waktu luang para siswa, inisiasi pembentukan Sanggar Sangku Lerong bertujuan untuk mendidik dan membina mental generasi muda serta diharapkan dapat berperan aktif di kehidupan bermasyarakat.

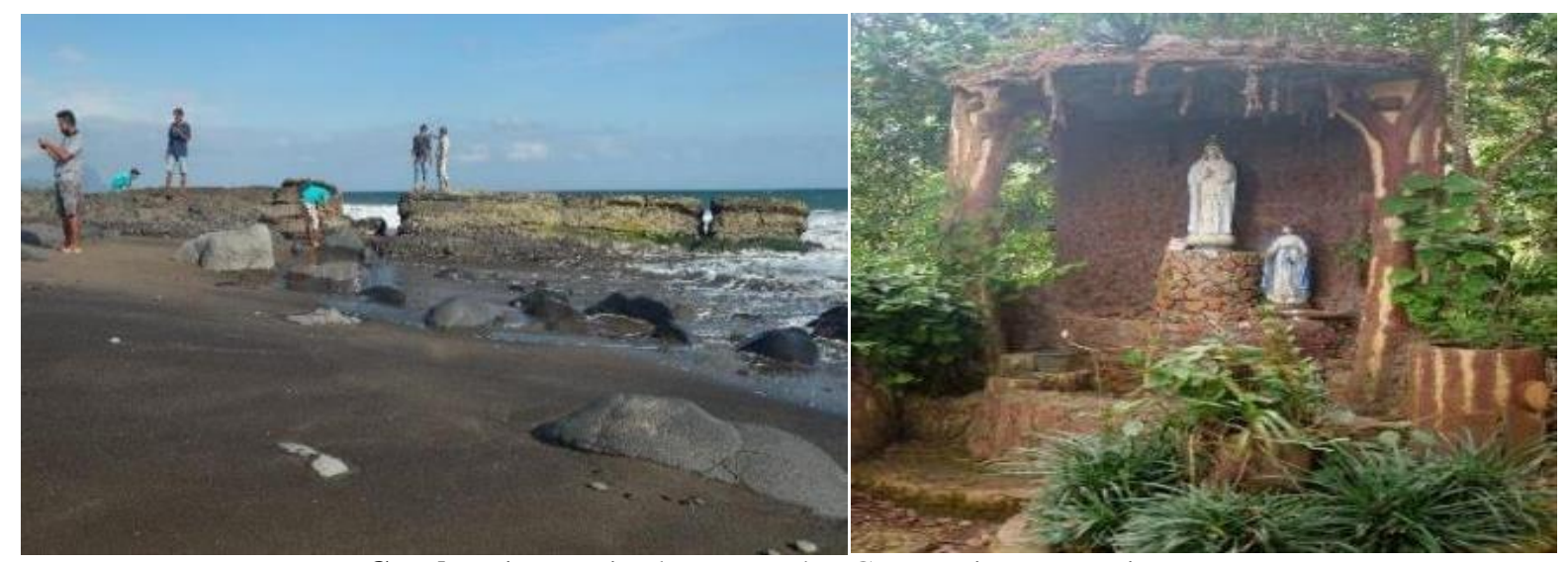

Gambar 1. Pantai Mberenang dan Gua Maria Pong Rojo Sumber: Hasil survei, 2020

Sehari-hari, sebagian besar kaum perempuan di Desa Watu Tiri melakukan aktivitas menenun. Namun, tenun hanya menjadi pekerjaan sampingan dan belum menjadi pekerjaan ataupun komoditas utama. Para penenun biasa menggunakan waktu luangnya seperti di siang menjelang sore hari selesai kegiatan berkebun, mengasuh anak, atau melakukan tugas rumah tangga lainnya. Mereka menenun di dalam atau di luar rumah dan tidak jarang juga di halaman belakang rumah yang menyatu dengan kandang ternak dijadikan tempat menenun. Para penenun umumnya mengerjakan tenunan sambil bercakap-cakap dengan kerabatnya agar tidak membosankan, meskipun pada waktu tertentu, mereka perlu berkonsentrasi karena desain dan motif yang dikerjakan cukup rumit. Rata-rata 1 (satu) lembar kain tenun songke bisa diselesaikan dalam waktu 3 - 4 bulan, namun jika rutin dikerjakan, 2 (dua) bulan pun bisa selesai. Setelah selesai, hasil tenun songke tersebut kemudian dijual di pasar terdekat, 
yaitu Pasar Lembor. Namun, tidak semua hasil pekerjaan tenun songke dijual, sebagian dari mereka membuatnya untuk dipakai sendiri atau digunakan pada saat upacara adat dan pernikahan. Belum adanya pengetahuan mengenai standar kualitas songke dan pemasaran yang belum maksimal menjadi permasalahan yang dihadapi.

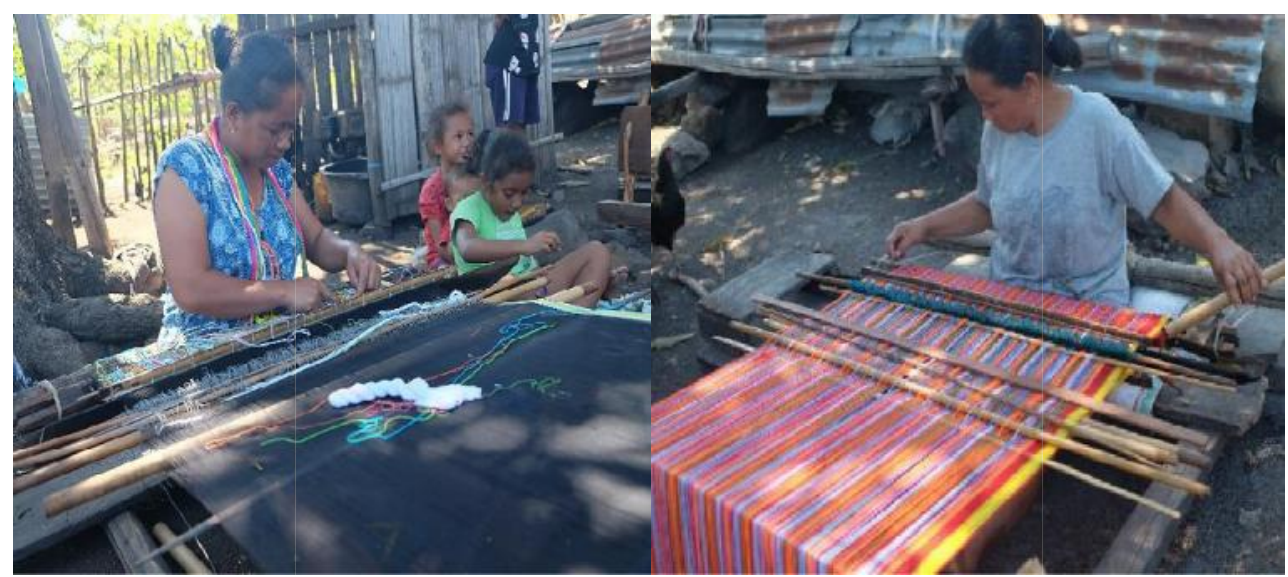

Gambar 3. Aktivitas Menenun Kaum Perempuan Sumber: Hasil Survei, 2020

Selain potensi pariwisata, beragam permasalahan pun muncul di Desa Watu Tiri, mulai dari yang sifatnya kebutuhan dasar seperti infrastruktur jalan yang kurang mendukung, jaringan telekomunikasi yang belum memadai, hingga kendala dalam hal pengembangan pariwisata. Masyarakat menyadari bahwa sumber daya manusia, khususnya bidang pariwisata, masih sangat rendah. Masyarakat membutuhkan pendampingan dalam perumusan rencana pengembangan Desa Watu Tiri sebagai desa wisata.

\section{Simpulan}

Melalui Kegiatan pengabdian masyarakat dapat disimpulkan mengenai potensi, produk pariwisata, kelompok masyarakat, permasalahan, dan cita-cita masyarakat dalam pengembangan. Desa Watu Tiri memiliki potensi alam, yaitu Pantai Mberenang dan Mata air panas. Produk wisata yang bisa ditawarkan berdasarkan potensi tersebut diantaranya sport water (seperti berenang, surfing, dan memancing), dan menikmati pemandangan sunset. Selain itu, kegiatan menenun kaum perempuan dan upacara adat merupakan potensi pariwisata budaya yang bisa ditawarkan dalam produk wisata berbasis kearifan lokal. Solusi yang ditawarkan terhadap permasalahan yang dihadapi oleh masyarakat Desa Watu Tiri, diantaranya kegiatan pelatihan e-commerce untuk mempromosikan souvenir asli desa, pelatihan pemanduan wisata dan bahasa inggris, dan peningkatan mitigasi di Pantai Mberenang guna memperbaiki citranya. Solusi-solusi tersebut bisa dilakukan pada kegiatan pengabdian selanjutnya. Selain itu, melalui kegiatan ini terdapat peningkatan pengetahuan dan pemahaman masyarakat Desa Watu Tiri yang hadir tentang pariwisata. Pengetahuan dasar ini akan bermanfaat dalam merumuskan rencana pengembangan terbaik Desa Watu Tiri sebagai desa wisata yang berbasis pada kearifan lokal.

Mengingat urgensi kerjasama pengembangan Desa Watu Tiri sebagai desa wisata masih dalam tahap identifikasi awal kebutuhan pengembangan, maka perlu dilanjutkan sejumlah kegiatan berupa: 1) FGD terkait perumusan rencana pengembangan, meliputi konsep, strategi, program, dan indikasi kegiatan dalam hubungannya dengan pengembangan desa wisata; 2) Workshop terkait tata kelola/kelembagaan desa wisata; 3) Pendampingan dalam penguatan dan pengemasan produk pariwisata; 4) Pelatihan sebagai upaya peningkatan kapasitas masyarakat, contohnya pelatihan Bahasa Inggris, pembuatan souvenir lokal, pemanduan wisata, serta promosi dan pemasaran pariwisata. 


\section{Ucapan Terima Kasih}

Penulis mengucapkan terima kasih kepada Ketua Yayasan Bangkit Anak Negerikut, Direktur Politeknik eLBajo Commodus, dan Kepala Desa Watu Tiri atas bantuannya dalam terwujudnya kegiatan pengabdian masyarakat ini.

\section{Referensi}

Susilawati, D.A.P. (2010). Peranan Museum Nusa Tenggara Timur Dalam Pembelajaran Dan Pelestarian Tenun. Universitas Indonesia : Depok.

Ulla, Keech-Marx. (2002). Komersialisasi Tenunan Songke: Dampaknya Terhadap Masyarakat Manggarai. ACICIS \& South East Asia Centre Australian National University.

Kecamatan Lembor Selatan Dalam Angka 2018. (2019). BPS Manggarai Barat.

Kementerian Kelautan dan Perikanan. Profil Kawasan Konservasi Perairan Nasional:Taman Nasional Perairan Laut Sawu Dan sekitarnya di Provinsi Nusa Tenggara Timur di https://kkp.go.id/djprl/bkkpnkupang/page/352-profil-tnp-laut-sawu. (diakses 20 Juli 2020).

Pemerintah Desa Watu Tiri. (2019). Rancangan Pembangunan Jangka Menengah Desa Watu Tiri.

Hudayana, B. et al. (2019). Participatory Rural Appraisal (PRA) untuk Pengembangan Desa Wisata di Pedukuhan Pucung, Desa Wukirsari, Bantul. Bakti Budaya. Vol. 2 No. 2.

Triyono, A. (2014). Pemberdayaan Masyarakat Melalui Community Development Program Posdaya (Pos Pemberdayaan Keluarga) Pt. Holcim Indonesia Tbk Pabrik Cilacap. KomuniTi, Vol. VI, No. 2. 